\title{
STRATEGIC HUMAN RESOURCE MANAGEMENT PRACTICES OF WESTERN MNES IN AFRICA: STANDARDIZATION, LOCALIZATION OR BOTH?
}

\author{
Theophilus Azungah
}

Bolgatanga Polytechnic, Republic of Ghana

tazungah@yahoo.com

\begin{abstract}
When Western multinational enterprises seek to transfer their preferred strategic human resource management (SHRM) practices to their subsidiaries in Africa, they face numerous challenges. Some of these challenges arise from Africa's particular cultural and institutional features. In Africa, parent country nationals (PCNs) prefer to standardize SHRM practices embedded in western values while host country nationals (HCNs) prefer to localize practices in accordance with African cultural and institutional specificities. This conceptual paper analyzes research on the motives and strategies for standardization and localization of SHRM practices and develops a set of propositions on how these practices are utilized in African subsidiaries of western multinationals. On the basis of published case examples I illustrate preferences for standardization, localization and a combination of both approaches. I discuss the implications of my study in terms of future research directions and lessons for practitioners.
\end{abstract}

Keywords: MNEs, Africa, HRM, HCNs, PCNs, localization, standardization, dual approach.

\subsection{Introduction}

A multinational company decided to try to boost employees' morale and enhance the productivity of employees by providing them with lunch. The workers resisted management's action and demanded that instead the cost of the meal be paid directly to them. The workers queried the action of management with the reasoning, 'How can we eat while our families go hungry?'

The above situation described by Schneider (1998: 238), relates to a Western multinational enterprise (MNE) operating in Africa. It demonstrates the collectivist culture of Africa and the challenges arising when western MNEs seek to implement company practices from their home country in their African subsidiary operations without taking sufficient account of local specificities; which are numerous and include cultural as well as institutional aspects.

Africa is deemed the most ethnically and linguistically diverse region of the world, with African ethnicities characterized by economic traits and distinct cultural norms (Michalopoulos \& Papaioannou, 2013, 2015). The level of inequality across ethnic groups in Africa is 
much higher than in other continents and differences in geographic endowments across ethnic localities and the inability of central governments to manage those intensify the already existing ethnic disparities (Alesina, Michalopoulos, \& Papaioannou, 2012).

In addition, many African economies are believed to be institutional voids (Gardner, 2011) with several culturallygrounded challenges (Osabutey, Nyuur, \& Debrah, 2015). Gardner (2011: 1) attributes the prevalence of these institutional voids as creating the basis for social contracts - "beliefs, unwritten rules of behavior, familial ties, social and moral norms of a given social community'; and social institutions - "the social hierarchy as promoted by traditional and religious leaders". In other words, in the absence of strong institutions, social norms regarding expected behavior prevail.

Notwithstanding the above challenges Africa has significant strategic investment prospects. Referred to as 'lions on the move'(McKinsey Global Institute, 2010), it has a population of over one billion in its 54 countries and emerging economies such as Botswana, Ghana, Mauritius, Cape Verde, Lesotho, Mauritania, Namibia, South Africa and Swaziland are making great strides in economic performance (Kehl, 2007). In 2014 Africa became the second largest recipient of capital investment (which had a nominal value of US $\$ 127.9$ billion) and the fastest-growing destination for foreign direct investment (FDI) funding. A total of 188,400 jobs were expected to be generated from these FDI investments in 2014 against 112,200 new jobs created in 2013 (Ernst
\& Young, 2015). Expansion into Africa is indeed part of a growth cycle that involves increases in FDI of Western MNEs.

Regardless of Africa's increasing economic importance, compared to developing economies in Eastern Europe, Asia, and Latin America, academic research on Africa is relatively weak (Bloom, Canning, and Chan, 2006). Though research on human resource management (HRM) and general management in Africa has been increasing (Aryee, 2004; Budhwar \& Debrah, 2001; Jackson, 2004), Africa has relatively been "truly terra incognita" in the field of strategic management (Mellahi \& Mol, 2015: 202) despite strategic management's "theorized importance to the competitiveness of firms and the fact that Africa ranks amongst the least in global competitiveness of firms" (Adeleye \& Anibaba, 2014: 286).

Against a background of regional diversity and strategic opportunities but limited academic research, the present paper focuses on the cultural and institutional challenges that western MNEs face when they seek to transfer their preferred strategic human resource management (SHRM) practices to their subsidiaries in host nations in the African continent. SHRM is "the pattern of planned human resource deployments and activities intended to enable the firm to achieve its goals" (Wright \& McMahan, 1992: 298) and has four components: HR as the primary resource to be leveraged as a source of competitive advantage; HRM programs, policies and practices as the means through which people are deployed to gain competitive advantage; the importance of fit with the firm's 
strategy and alignment across HRM activities; and goal achievement with an emphasis on maximizing organizational performance (Wright, 1998). Kostova (1999) points out that the success of the transfer of practices is determined by the diffusion of rules describing the practices, and the value and knowledge associated with the practices.

When MNEs endeavor to transfer SHRM practices to their foreign subsidiaries, they typically achieve either standardization or localization of practices. Smith (2008: 319) observes that "there is little doubt that effective management is a blend of universal processes and specific local issues. The question that remains open for debate is the relative preponderance of the universal and the local". The prevalence of universal or local issues can result from a dilemma between satisfying the interests of the parent company or those of local stakeholders (Kostova \& Roth, 2002) and this leads to decisions about the degree of standardization or localization that occurs. Such standardization or localization may be strongly influenced by whether the managers of the subsidiaries are parent country nationals (PCNs), also known as expatriates, or host country nationals (HCNs), also known as local staff. In this paper I explore how PCNs and HCNs in western MNE subsidiaries influence the extent to which SHRM practices reflect standardization or localization and examine where a dual approach may result from interplay of the local context and parent country practices. In so doing I extend the scholarly conversation on challenges that western MNEs face when transferring their SHRM practices to less developed countries to an examination of Africa. Given its importance and diversity, Africa provides a fascinating research context.

The remainder of this article is organized as follows. In the following section I provide an overview of Africa's cultural and institutional context. I then present my analysis of the standardization of SHRM practices, localization of SHRM practices, and integration of localization and standardization in a dual approach to SHRM practices. I illustrate this discussion with case examples from countries that represent the geographic scope and cultural diversity of the continent - Nigeria in the West, Tunisia and Algeria in the North, Tanzania in the East and Mozambique in the South-East. my key arguments are synthesized in a set of theoretical propositions and I provide a model which depicts and puts together these propositions. In the final section I conclude and suggest directions for future research, and outline implications for practice.

\subsection{The Literature Review Method}

Iused the following key concepts stated in the propositions namely, "western MNEs", "standardisation", "localisation", "HCNs", "PCNs" "HRM practices", "interplay" to search for articles on SHRM practices in MNEs. I also conducted further searches using the following data sources: Science Direct, Google Scholar, Emerald Journal, Emerald Management Xtra, ABI/INFORM, Business Monitor International, JSTOR, Science Direct, 
and Wiley Online Library, among others. I conducted both forward and backward snowballing. Forward snowballing refers to "identifying articles that have cited the articles found in the search and backward snowballing from the reference lists" (Jalali \& Wohlin, 2012: 29). Backward snowballing starts with the knowledge of a few articles in the areas of interest and finding out from the reference lists those relevant articles that have been cited and subsequently retrieving them. The process continues with new articles retrieved until no more relevant articles are found (Sayers, 2007). I snowballed from the reference lists of journal articles and books to identify additional relevant sources of literature. Some of the books were mentioned in the reference lists of journal articles. Some of the major journals and books included in this study are: Academy of Management Review, International Journal of Management Reviews, Journal of International Business Studies, Journal of Management, Global Strategy Journal, Africa Journal of Management, The Academy of Management Perspectives and other books including The Routledge Companion to Business in Africa, Managing Human Resources in Africa, Handbook of Human Resource Management in Emerging Markets, Human Resource Management in Developing Countries. Subsequently, I organized my review thematically by grouping topics I found in key researches related to my study.

\subsection{Africa's Cultural and Institutional Context}

I now describe in detail some of the cultural and institutional specificities of the African context.

\section{Cultural specificities}

Africa is not a homogenous entity; it is instead characterized by a high degree heterogeneous cultures (Kamoche, 2002; Osabutey et al., 2015) with about 2000 different languages (Beugre, 2015). In many African cultures the ethnic group is a major source of identity. Huge tribal and ethnic differences can be found within a country (Beugre \& Offodile, 2001). At the same time, certain common trends exist in Africa's multicultural, multi-ethnic and multilingual portrait. Writing about the socio-cultural context of Ghana (which may also be applicable to other African countries), Gyekye (2014: 161) notes:

'It is impossible, in fact incon -ceivable, for peoples who have lived closely together for many, many decades not to affect one another culturally. [...] It would therefore be correct to say that cultural interpenetration through cultural contacts, exchanges and borrowing or appropriation of values, ideas, practices and institutions has resulted in the emergence of common or shared cultural values and practices.'

Beugre and Offodile (2001) note that some of the cultural commonalities in Africa are collectivism, uncertainty 
avoidance, respect for authority, family orientation, power distance and respect for elders. While Gyekye (1988: 3132) points out that African societies exhibit features of both individualism and collectivism which he describes as amphibious in order "to avoid the excesses of the two exaggerated systems", in a number of African countries, such as Ghana, Tanzania, South Africa and Nigeria, emphasis is often placed on the group rather than the individual, leading to preference for consensus in decisionmaking. The collectivist spirit, captured in the South African notion of Ubuntu, is grounded on the fact that "people are only people through other people" (umntu ngumntu ngabanye). Ubuntu is closely associated with the process of indaba which refers to involvement of employees in decision-making with an ultimate aim of achieving consensus (Jackson, 2002; Mangaliso, 2001).

In an effort to gain legitimacy in the African context, Western MNEs may apply the principles underlying Ubuntu to motivate employees through employee recognition, mutual respect, sharing of bonuses, and intermittent interactions between management and subsidiary employees. Also, consensus based decision-making through negotiations with employees can enhance commitment and loyalty to corporate goals. When employees are respected and dignified, they may feel intrinsically satisfied, and this can generate a symbiotic effect of greater allegiance to the MNE and its overall goals. According to the philosophy of Ubuntu, Organisations are 'nurturing communities' (Dobson: 1997: 148) and management is expected to provide and enabling environment for participatory decision-making.

Additionally, age is highly revered in the African context. Age is deemed not a hindrance associated with senility (Mangaliso, 2015). In some African countries it is believed that age is closely linked with experience and knowledge. Therefore, within a community or organization an older person can promote the spirit of co-operation within an organization. Seniority is respected in organisations because it is believed that a long-serving employee has more experience and knowledge of the business context than junior employees. Employees are motivated to stay longer in organisations if seniority and age are respected (Chen \& Miller, 2010) and consequently increase the stock of experienced talent. The networks developed over the years during one's working life are very useful for nurturing good relations with clients (Mangaliso, 2001). Honouring seniority and age is also a means of recognising individuals for their past contributions to the organisation. In HRM practices such as recruitment, selection and promotion, seniority (either in terms of chronological age or service to the company or experience in the position), can be taken into consideration particularly when a pool of potential candidates have equal qualifications.

Another important characteristic is tradition. Ethnic identification is strong in Africa and it "fosters interaction within group members and limits communication between groups" (Michalopoulos \& 
Papaioannou, 2015:35). Ethnic identification is stronger than national identification particularly among the rural folks in some African countries (Michalopoulos \& Papaioannou, 2014). National and ethnic identification concur in most African countries, a characteristic related to the dual governance system where traditional and national laws are operationalised (Michalopoulos \& Papaioannou, 2015).

\section{Institutional specificities}

The multi-layered cultural differences within and across African countries are reflected in Africa's institutional complexity (Nyuur, Osabutey, \& Debrah, 2014). In that sense, understanding the institutional environment of one African country may not necessarily translate into understanding institutions prevailing in another African country. In addition, the large institutional distance between Africa and the Western world poses challenges that can seriously impede the implementation of western MNEs' preferred SHRM practices in their African subsidiaries.

In Africa formal institutions such as courts and other legal mechanisms have high costs and are therefore seldom utilized and as a result, "informal arbitration often becomes a default option in alleviating uncertainty and resolving disputes" (Peng, 2014: 13). The Economist (2005: 1) reports that "over $40 \%$ of Africa's economy is informal - the highest proportion in the world." Further to this, Acquaah (2007: 1240) observes that in Ghana, as in many other African countries, 'there are two parallel political systems and authorities: (1) the formal political system of the modern nation state, and (2) traditional political systems that pre-date the modern nation state.' Chiefs help to instill discipline and to "improve the legitimacy and enforceability of rule of law and property rights" (Dia, 1996: 106). This is not surprising bearing in mind that about 80 percent of land is customarily owned by families, clans and traditional authorities, such as chiefs, in Ghana (Kasanga \& Kotey, 2001).

Western MNEs, particularly those in the extraction industry, have to negotiate with government, tribal leaders and chiefs for lease of land and payment of royalties in many African countries. Chiefs are also influential in mediations between their communities and MNEs in times of crises where community members protest against actions of organizations. Acquaah (2007: 1240) points out that 'in Africa, community leaders such as local chiefs and kings and religious leaders are very influential in garnering resources and providing access to valuable informationand knowledge to businesses.' In fact, the national constitutions of some countries, such as Ghana and Uganda, recognize ethnic institutions in the settlement of property rights, disputes, and enforcement of customary law (Michalopoulos \& Papaioannou, 2013). Indicative of such informal institutions is the following example about Kgotla and the palaver tree. 


\section{Working with informal institutions in Africa: \\ Can MNEs use Kgotla and the palaver tree?}

In applying their HRM practices, MNEs may draw some inspiration from certain customs in some African countries. For instance, the Kgotla governance system in Botswana is analogous to the Palaver tree in some west and central African countries. (Western readers may indeed be familiar with the English-language term palaver-meaning a conference or conversation, with connotations of superfluous idle talk - without realizing its African origins).

Both the Kgotla and the palaver tree are places designated for community meetings. The Kgotla is headed by a chief, and in the Kgotla system community members meet to discuss issues of mutual interest, while the palaver tree is the „local shade of the sacred baobab or mango trees ${ }^{\text {ee }}$ in villages (Land, 1992: 10) beneath which African people traditionally meet to discuss community issues under the leadership of village elders (Leach \& Mearns, 1996). In Kgotla meetings discussions are held in an atmosphere of mmu a lebe o bua la gagwe (everybody is free to speak candidly, and even make mistakes). Government officials equally use the forum to disseminate information on new policies and legislation (Lekorwe, 2011).

The palaver tree also serves as an avenue where multiple viewpoints are discussed extensively to arrive at a consensus (Land, 1992; Leach \& Mearns, 1996). It is also a rallying point for social events such as festivals (Land, 1992). By extension, western MNEs may use their town hall fora and staff durbars where employees from different linguistic and tribal backgrounds in the African region are assembled, to elicit certain hidden sociocultural and institutional assumptions underlying their worldviews of work. These fora can also be grounds for negotiations on acceptable SHRM practices. Employees can be encouraged to speak on issues concerning subsidiary business and SHRM practices without fear of reprisals. Such exposure to plural viewpoints can facilitate the clarification of SHRM practices to employees.

\subsection{Standardization, Localization or a Dual Approach?}

In this section I develop propositions based on my analysis of prior literature and cases which highlight where MNEs have followed standardization, localization or a dual approach.

\section{Standardization of SHRM practices}

MNEs aim to transfer to their overseas subsidiaries SHRM practices that reflect the core business values and competencies established in the MNEs' home countries. The transferred SHRM practices are believed to be sources of synergy, efficiency and competitive advantage (Kostova, 1999). Western MNEs transfer their preferred SHRM practices to Africa with the intention to gain perceived advantages of superiority, consistency, effectiveness and competitive advantage (Kamoche \& Newenham-Kahindi, 2012; 
Mellahi \& Frynas, 2003). The transfer of SHRM practices is intended to standardize the SHRM practices throughout the various units of an MNE, facilitating coordination and interaction (Jain, Lawler, and Morishima, 1998; Festing et al., 2010; Rosenzweig \& Nohria, 1994). Such standardization is intended to "smooth the transfer of MNE competencies across the organization" (Wocke, Bendixen, \& Rijamampianina, 2007: 829). Moreover, it is designed to ensure alignment of SHRM practices with overall business strategy for the international operations. In such instances, elements such as industrial relations, labor market institutions, HRM practices developed and implemented at the MNE headquarters (HQ) are often carried over to a subsidiary (Ferner, 1997). For instance, in their international operations US companies usually favor performance-related pay, Japanese companies prioritize seniority-based pay whilst German companies rely on their co-determination system which includes workers' representatives' councils and apprenticeship training (Ferner, 1997;
Ferner \& Quintanilla, 1998; McDonnell et al., 2011).

This ethnocentric transfer of management practices to the African region can be traced as far back to colonial rule of the African continent. Kiggundu (1991: 34) observes that:

'During colonization, the various colonial powers first destroyed or denigrated local institutions and management practices, and then developed their own colonial administrative systems. [...] because the colonists were convinced of their cultural, biological, and technological superiority and the inferiority of African administrative systems.'

It has been suggested that the destruction of indigenous organizations and management systems amounts to depriving Africans of practices that are more situationally appropriate (Kiggundu, 1991). The following case illustrates the ethnocentric standardization approach.

\section{Citibank: Corporate colonialism in Tanzania}

Kamoche and Newenham-Kahindi (2012) examine the transfer of American HRM practices of Citibank to its subsidiary in Tanzania, a former British colony located in East Africa. In this case recruitment of local employees was conducted at HQ and targeted at graduates between the ages of 18 and 35 years. Employment was on contractual terms and therefore not permanent. Promotion was based on merit regardless of age and gender. The Bank established resource centers for training its employees. All training materials and content originated from the USA. The Bank also used ICT to train its employees in the various software packages that were developed and tested at HQ. New recruits underwent induction training where the Bank ${ }^{e e} \mathrm{~s}$ vision, mission and strategy were explained to them.

Citibank practiced "Americanization of the workplace" by adopting a practice of cultural assimilation in line with the supposed "best practices" approach. The 
company further assumed that the strength of the American educational system, coupled with the reputation of management philosophies originating from America, gave it no other choice than to apply an American style of HRM. Employees were constantly reminded that when dealing with customers from America or Europe they should use "appropriate" customer relations, including using an American accent. The physical setting of the work place was also Americanized, with a living room furnished with American newspapers and televisions with foreign channels. Because expatriates had the skills and know-how to run the business, CitiBank used them to strengthen its SHRM practices: they occupied key positions including training local employees. They ensured compliance with formal procedures. Induction and recreational activities were designed to infiltrate the culture of the host context.

However, some transferred practices caused employees discomfort and were considered inappropriate. For instance, work/life balance programs - implemented without any consultation with the subsidiary's employees - were considered an unnecessary intrusion into their private lives. Additionally, employees were individually assessed for the purpose of promotion and salary increases based on the American value of individualism. Weaver (1999) observed that individualism, with an emphasis on self-reliance, independence, and achievement, is valued in the American context. It contrasts however in many African countries employees are assessed in groups (Sartorius, Merino, \& Carmichael, 2011). Citibank's control of its subsidiary management from HQ without consultation with local actors is regarded as insensitive.

As in the Citibank case, PCNs facilitate the integration of strategies of subsidiaries and parent company through coordination and control. They also facilitate the transfer of knowledge between subsidiary and parent company (Gaur, Delios, \& Singh, 2007). PCNs function as 'role models', 'boundary spanners', and 'coaches' (Hetrick, 2002) and are likely to implement SHRM practices of the home country in overseas subsidiaries to ensure alignment with their intended business strategy for the subsidiary operation. This leads us to put forward:

Proposition 1. Despite the complex and challenging cultural and institutional context of Africa, PCNs prefer to standardize SHRM practices in Western MNE subsidiaries in Africa.

\section{Localization of SHRM practices}

Cultural forces act as countervailing forces for the transfer of foreign SHRM practices. Some MNEs'usual home-based practices may have to be adjusted to comply with local norms and preferences (Bjorkman and Lervik, 2007; Farndale, 2010; Festing et al., 2010), which results in practices' localization. In contrast to the ethnocentrism of standardization, localization of SHRM practices is associated with polycentrism where the host country's beliefs and practices prevail over the use of practices from the 
country of origin of an MNE (Heenan \& Perlmutter, 1979; Perlmutter, 1969).

Cultural forces create pressures for MNEs to decentralize decision-making about SHRM issues in order to conform to, and become legitimate in, the local context. The transfer of parent country SHRM practices to culturally-distant foreign subsidiaries can possibly be unproductive (Kim \& Gray, 2005). As per Tayeb (2005: 102), the parent company of an MNE cannot easily do away with 'its host-country employees' cultural attitudes, values and beliefs (sic) from a distance and through rules and regulations' in order to implement its preferred practices. For that reason, stakeholders such as local managers and unions are likely to reinterpret, negotiate or adapt selected practices to suit the context (Yahiaoui, 2015).

Xing et al. (2014: 7) observe that "work constitutes only part of the African employees' life, and community life and family are more important". This is a manifestation of the Ubuntu principle of treating others as your brothers and sisters: 'I belong, therefore I am' (Xing et al., 2014: 7). In this case foreign managers adapted to local customs and granted African employees religious holidays and showed respect for their culture. The next two case examples illustrate the localization approach:

\section{Swedish and Swiss subsidiaries in Nigeria}

Swedish and Swiss subsidiaries in Nigeria employed host country nationals as line managers. Mamman, Baydoun, \& Adeoye (2009) noted that because the content of performance management practices was formulated in the home countries without the input of the Nigerians, these practices were largely ethnocentric. Host country employees felt their views were not taken into consideration during the appraisal process; thus reflecting the power distance of the Nigerian context. Mamman et al. (2009) described the process of implementing the performance management practices as informal adaptations by the local managers to suit the Nigerian traditional context of power distance and humaneness; suggesting that the transfer process was probably influenced by the nationality of persons implementing decisions. While western values are centered on universalism and based on performance criteria, those of Nigeria are based on particularism and kinship. Mamman etal. (2009: 4) conclude that, even if MNCs adopt an ethnocentric policy, local managers would modify the system anyway.

\section{French subsidiaries in Tunisia}

Yahiaoui (2015) examined HRM practices in French subsidiaries in Tunisia, a country located in North Africa that became independent from France in 1956. The HQ of one of the companies introduced variable pay linked to company targets. However, local employees preferred an increment based on fixed pay rather than variable pay relying on individual and overall company performance and 
profitability. Employees pressured management to modify the system to enable all of them to benefit. Accordingly, the local managers increased the fixed part more than the variable portion of pay. They also considered the skills evaluation criteria transferred from the HQ to be too high and rigid for the Tunisian context and consequently adapted them. The adjustment was made to maintain group solidarity and to align with the Tunisian collectivist culture. Because employees regarded criticisms and penalties as individual affronts, performance appraisal practices were also modified to remove penalties. This case underscores the need for MNEs wanting to do businesses in Tunisia to uphold cultural values such as: respect for elders; cooperative management style; consensus through negotiation; dignity; and pride in the local context.

Thus, as Horwitz (2009) points out in reference specifically to the Southern African context, the 'as is' adoption of SHRM practices defeats the purpose of achieving corporate goals and underscores the need for sensitivity to the local context. For instance, performance-based pay and variable pay may be effective across the African context if they are geared towards workgroup or team based arrangements.

HCNs tend to emphasize local values, norms and beliefs (Mamman et al., 2009) and are likely to adapt SHRM practices to suit their local context. The pressure for local legitimacy may be particularly high in Africa as the continent as such is institutionally hugely distant from western MNE home countries. HCNs help foreign subsidiaries to provide knowledge of customer needs, business practices, language, cultural preferences and how best to manage and motivate local employees (Konopaske \& Ivancevich, 2004). In so doing they facilitate achieving strategic alignment between the SHRM practices utilized and the overall business goals for the subsidiary operation. This leads us to propose that:
Proposition 2: Given the huge diversity of the cultural and institutional contexts in Africa, HCNs prefer to localize SHRM practices in Western MNE subsidiaries in Africa.

\section{A dual approach to SHRM practices}

For effective and appropriate application of foreign SHRM practices in Africa, Jackson (2004) suggests that managers should be cognizant of both endogenous and exogenous factors that might influence their decisions and actions. Thus it is reasonable to argue that for Africa a dual management approach incorporating both standardized and localized values, beliefs and practices is vital. Moreover, finding the right balance between standardization and localization can lead to mutual learning and compromises (Gamble, 2003). According to Laurent (1986: 97):

"In order to build, maintain, and develop their corporate identity, multinational organizations need to strive for consistency in their ways of managing people on a worldwide basis....to be effective locally, they 
also need to adapt those ways to the specific cultural requirements of different societies."

The following three examples demonstrate a dual approach to transfer of SHRM practices. One of them can be classified as driven by standardization and the following one as driven by localization. Mellahi and Frynas (2003) discussed an Algerian automotive firm where, despite the imposition of western practices, local employees devised their own informal collectivist practices to suit the Algerian context. The other two cases are based in Tunisia and Mozambique respectively.

\section{Can top management enforce standardization in the Algerian context?}

Mellahi and Frynas (2003) analyzed the transfer of German and French work practices to an Algerian automotive firm. The firm sought to implement standardized work practices from a similar French company while some practices were imposed on the firm following the installation of a new technology it imported from Germany. According to Mellahi and Frynas (2003: 75) management justified the transfer of SHRM practices based on economic and technical resons but failed to "identify local conditions under which these HRM practices"would sucessfully work resulting in "unplanned and haphazard importation of western HRM practices". Shop floor employees strongly resisted Western individualized work practices and adapted them to suit the Algerian collectivist work norms and values. Their immediate supervisors tacitly approved these informal ways without the knowledge of management who emphasized western individualized work practices. The researchers concluded that management ironically argued that the mismatch between cultural norms and work values originated from the failure of workers to abandon their cultural values. The workers further contended that individualised work practices resulted in inefficiency and "other negative feelings associated with the perception of being forced to adopt and accept practices which run counter to deeply held values and assumptions of the local culture" (Mellahi and Frynas, 2003: 76).

\section{Is the local culture really that resilient in Tunisia?}

Yahiaoui (2015) noted that French subsidiaries in Tunisia relied on interview guidelines and selection criteria developed by HQ for recruitment and selection of employees. In this case however, the subsidiaries included in their selection criteria wasta (an Arabic term for personal relations), trust and age of job applicants. Additionally, the HQ transferred human resource planning and forecasting activities to the subsidiaries but these were implemented with modifications. Both HQ and the subsidiaries identified tenure end for employees and evaluated the recruitment budget accordingly. Unlike HQ that recruited based on skills needed, the subsidiaries extended contracts of existing employees on the shop floor based on relations and paternalism in conformity with the collectivist notion that managers are expected to take care of employees. 
Managing the opposing forces of localization and standardization of HRM practices simultaneously necessitates negotiations between management and employees to achieve the MNE's strategic business goals. MNEs often argue that local practices are not competitive (Bjorkman \& Budhwar, 2007) and hence would not align with the business strategy for their operations; thus implying that standardization and localization cannot be simultaneously implemented. A differing view is that localization and standardization are not mutually exclusive but are implementable and attainable at the same time with varying emphasis on aspects of the practices (Berchtold, Pircher, \& Stadler, 2010).

I suggest that interplay simultaneous application of standardization and localization of SHRM practices in subsidiaries of Western MNEs is feasible. The interplay between the two approaches may permit subsidiaries to take advantage of opportunities that stem from the local environment and still fulfill the MNE's expectations of the subsidiary (Mudambi, 2011). Thus, while PCNs may generally choose to standardize and HCNs may prefer to localize, in some organizations negotiation facilitates a dual approach in implementing SHRM practices consistent with overall MNE strategy. This leads us to advance the following:

Proposition 3. The interplay between the cultural and institutional forces in Africa and parent country practices results in the adoption of a dual approach to SHRM practices in Western MNE subsidiaries in Africa.
Based on the preceding propositions, I present a model which I illustrate in Figure 1 to demonstrate the relationship between MNC parent company SHRM practices and the subsidiary SHRM practices (Proposition 1), the relationship between host country local context and subsidiary SHRM practices (Proposition 2), and the dual approach of an interplay between MNC parent company SHRM practices and the host country local context for subsidiary SHRM practices (Proposition 3).

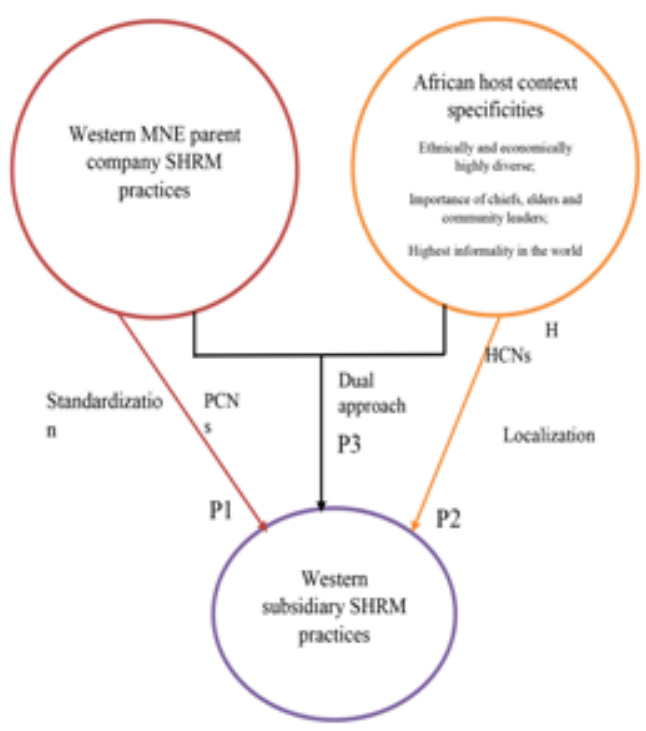

Figure 1: SHRM practices in Western MNEs in Africa

\subsection{Conclusion and implications}

In this paper I have argued that in the complex and challenging cultural and institutional context of Africa, PCNs prefer to standardize SHRM practices in Western MNE subsidiaries in Africa while HCNs prefer to localize them. I have also argued that although there are serious challenges in finding a suitable balance between localization and standardization of SHRM practices, transfer of these 
practices may be considered a symbiotic interaction between PCNs, HCNs and other relevant actors/stakeholders in the local context. Balancing standardization and localization can enhance mutual learning and contribute to achieving both HQ's and subsidiaries'goals. In particular, Western MNEs are likely to benefit from improved work relationships with $\mathrm{HCNs}$ and local employees have the opportunity to acquire new knowledge and skills. By highlighting, through case studies of a range of MNEs in varying countries in Africa, the distinct, heterogeneous cultural and institutional features of Africa which impact on MNEs' strategic choices and practices, the article extends the existing literature on SHRM in developing countries to a previously little examined, but economically important region. In particular, I identified how MNEs from parent countries that are culturally and institutionally distant from Africa can navigate through some important complex challenges.

This study is of explorative nature. Studies on African management in general and on African HRM in particular are rare and scattered (Elliss, Nyuur, \& Debrah, 2015). Because of that, it is difficult to know in advance what the key processes and constructs are pertaining to SHRM practices and their transfer in the context of the operations of western MNEs in the African continent. Moreover, the existing literature on SHRM practices is embedded predominantly in western thinking (Pudelko \& Harzing, 2007) and as such, it has its own ethnocentric origin. Scholars have noted challenges associated with conducting research in Africa, including lack of indigenous theories and limited applicability of existing western models (Lages, Pfajfar \& Shoham, 2015).

Due to the nascent state of literature on SHRM practices in Africa (Mellahi \& Mol, 2015), I suggest that qualitative research, in particular, may be useful to explore in greater detail how SHRM practices are transferred to subsidiaries located in Africa. Qualitative research would allow meaningful contextualization of research questions on SHRM practices in the context of Africa. It would be preferable to avoid hypothesizing relationships between variables in a context with several unexplored issues relating to SHRM until qualitative research can bring more clarity into the understanding of the key concepts related to this complex process. For instance, I have emphasized that Africa has the highest rate of informality in the world (The Economist, 2005) and I have touched upon the importance of chiefs, elders, and community leaders in the African context. However, there is huge potential in many more and far deeper analyses of these actors and/ or other informal institutions and their influence on SHRM practices. Detailed, rich and evocative data are needed to shed light on the SHRM practices transfer as an important, yet not well understood phenomenon in the African context.

The practical implications of my analysis point to the need for HQ executives in the parent country to carefully evaluate the institutional environment of the respective African host country where their subsidiaries are located before making decisions on the suitability of the particular SHRM practices and 
their transfer. Prior experience gained in other contexts, including in other developing countries, may not necessarily be transferrable to and useful in the African context. Indeed, Klingebiel \& Stadler (2014: 3) observed that 'when Western investors arrive in Africa for the first time, they soon notice that their prior experience is of limited use. Many get burned and pack up quickly. Others see the continent's uncertainty as opportunity.' In that respect $\mathrm{HCN}$ nationals may act as an invaluable conduit between the African subsidiary and senior HQ executives in explaining and making sense of the specificities of the African context which MNEs need to consider if they are to be successful in achieving their strategic business and HRM goals.

Some of my case examples demonstrated that west-centric models of SHRM practices simply cannot be directly replicated in the African context and instead, require modifications. Thus, PCNs need to be flexible, accommodating and willing to negotiate with local stakeholders in the implementation of SHRM practices. Understanding the norms, values and beliefs valid and appreciated in the African context will help Western MNEs to adjust their practices to

work more effectively in African subsidiaries. Consultative decision-making with local chiefs/elders and employees is likely to result not only in more harmonious work environments and standing of the subsidiary in the local community, but result in employees being more effective in combining local practice with introduced SHRM practices.

\section{References}

1. Acquaah, M. (2007). Managerial social capital, strategic orientation, and organizational performance in an emerging economy. Strategic Management Journal 28(12), 12351255.

2. Adeleye, I. \& Anibaba, Y. (2014). Strategic human resources management, labour market efficiency and competitiveness in Africa. In Nwankwo S, and Ibeh K (eds.). The Routledge Companion to Business in Africa. Routledge: Abingdon, Oxon, UK: 286-295.

3. Alesina, A., Michalopoulos, S., \& Papaioannou E. (2012). Ethnic Inequality. NBER Working Paper No. 18512, National Bureau of Economic Research, University of Warwick, UK.

4. Aryee, S.( 2004). HRM in Ghana. In Kamoche KN, Debrah YA, Horwitz FA, Muuka GN (eds.). Managing Human Resources in Africa, Routledge: Oxon, UK: 121-134.

5. Berchtold, S., Pircher, R., \& Stadler, C. (2010). Global integration versus local adaptation: a case study of Austrian MNCs in Eastern Europe. European Journal of International Management, 4(5), 524-549.

6. Beugré, C. D., \& Offodile, O. F. (2001). Managing for organizational effectiveness in sub-Saharan Africa: a culture-fit model. International Journal of Human Resource 
Management, 12(4), 535-550.

7. Beugré, C. D. (2015). The Challenge of Management Scholarship in Africa. Africa Journal of Management, 1(1), 94-98.

8. Björkman, I., \& Budhwar, P. (2007). When in Rome...? Human resource management and the performance of foreign firms operating in India. Employee Relations, 29(6), 595-610.

9. Björkman, I., \& Lervik, J. E. (2007). Transferring HR practices within multinational corporations. Human Resource Management Journal, 17(4), 320-335.

10. Bloom, D., Canning, D., \& Chan, K. (2006). Higher education and economic development in Africa. Washington, DC: The World Bank.

11. Budhwar, P. S., \& Debrah, Y. A (eds). (2001). Human Resource Management in Developing Countries. Routledge, UK.

12. Chen, M. J., \& Miller, D. (2010). West meets East: Toward an ambicultural approach to management. The Academy of Management Perspectives 24(4), 17-24.

13. Dia, M. (1996). Africa's management in the 1990s and beyond: reconciling indigenous and transplanted institutions. World Bank Publications. Washington, DC.

14. Dobson, J. (1997). Finance ethics: the rationality of virtue. Rowman and Littlefield: Maryland, USA.

15. Ellis, F. Y.A., Nyuur, R. B., \& Debrah, Y. A. (2015). Human resource in Africa. In Horwitz, F., \& Budhwar P (eds.). Handbook of Human Resource Management in Emerging Markets, Edward Edgars. Cheltenham, UK: 393-425.

16. Ernst \& Young. (2015). EY's Africa attractiveness survey: Africa 2015: Making choices. Available at: www.ey.com/.../EY-africa-attractiveness-survey-2015.../EY-africa-attract accessed 13 September 2015

17. Farndale, E. (2010). What is really driving differences and similarities in HRM practices across national boundaries in Europe? European Journal of International Management, 4(4), 362-381.

18. Ferner, A., \& Quintanilla, J. (1998). Multinationals, national business systems and HRM: the enduring influence of national identity or a process of AngloSaxonization. International Journal of Human Resource Management, 9(4), 710-731.

19. Ferner, A. (1997). Country of origin effects and HRM in multinational companies. Human Resource Management Journal, 7(1), 19-37

20. Gamble, J. (2003). Transferring human resource practices from the United Kingdom to China: the limits and potential for convergence. International Journal of Human Resource Management, 14(3), 369-387.

21. Gardner, A. (2011). Emerging African Markets: MNCs must partner with NGOs. The African Executive Magazine, 12 January: 1-3.

22. Gaur, A. S., Delios, A., \& Singh, K. (2007). Institutional environments, staffing strategies, 
and subsidiary performance. Journal of Management, 33(4), 611-636.

23. Gyekye K. (1988). The unexamined life: Philosophy and the African experience. Accra. Ghana Universities Press.

24. Gyekye, K. (2014). Philosophy Culture and Vision: African Perspectives: Selected Essays. Sub-Saharan Publishers, Ghana.

25. Hannon, J. M., Huang, I. C., \& Jaw, B.S. (1995). International human resource strategy and its determinants: the case of subsidiaries in Taiwan. Journal of International Business Studies, 26(3), 531-554.

26. Heenan, D. A., Perlmutter, H. V. (1979). Multinational Organizational Development: A Social Architectural Approach. Reading, MA: Addison-Wesley.

27. Hetrick, S. (2002). Transferring HR ideas and practices: globalization and convergence in Poland. Human Resource Development International, 5(3), 333-351.

28. Horwitz, F. M. (2009). Managing human resources in Africa: emergent market challenges. In Storey, J., Wright, P. M, \& Ulrich, D. (eds.). The Routledge Companion to Strategic Human Resource Management, Routledge, UK.

29. Jackson, T. (2002). International HRM: A cross-cultural approach. London: Sage.

30. Jackson, T. 2004. Management and change in Africa: A cross-cultural perspective. Routledge, London.

31. Jain, H. C., Lawler, J. J., \& Morishima, M. (1998). Multinational corporations, human resource management and host-country nationals. International Journal of Human Resource Management 9(4), 553-566.

32. Jalali, S., \& Wohlin, C. (2012). Systematic literature studies: database searches vs. backward snowballing. In Proceedings of the ACM-IEEE International Symposium on Empirical Software Engineering and Measurement (pp. 29-38). ACM.

33. Kamoche, K., \& Newenham-Kahindi, A. (2012). Knowledge appropriation and HRM: the MNC experience in Tanzania. The International Journal of Human Resource Management, 23(14), 2854-2873.

34. Kamoche, K. (2002). Human resource management in Africa: Introduction. The International Journal of Human Resource Management, 13(7), 993-997.

35. Kasanga, R. K., \& Kotey, N. A. (2001). Land Management in Ghana: Building on Tradition and Modernity. Accra: University of Ghana.

36. Kehl, J. R. (2007). Emerging markets in Africa. African Journal of Political Science and International Relations 1(1), 001-008.

37. Kiggundu, M. N. (1991). The challenges of management development in sub-Saharan Africa. Journal of Management Development, 10(6), 32-47.

38. Kim, Y., \& Gray, S. J. (2005). Strategic factors influencing international human resource 
management practices: an empirical study of Australian multinational corporations. The International Journal of Human Resource Management, 16(5), 809-830.

39. Klingebiel, R., Stadler, C. (2014). What western investors want from African entrepreneurs. Available at: https://hbr.org/2014/11/what-western-investors-want-fromafrican-entrepreneurs (Accessed 11 August 2015).

40. Konopaske, R, \& Ivancevich, J. M. (2004). Global Management and Organizational Behaviour: Text, Readings, Cases and Exercises. New York: McGraw Hill Companies.

41. Kostova, T., \& Roth, K. (2002). Adoption of an organizational practice by subsidiaries of multinational corporations: Institutional and relational effects. Academy of Management Journal, 45(1), 215-233.

42. Kostova, T. (1999). Transnational transfer of strategic organizational practices: A contextual perspective. Academy of Management Review, 24(2), 308-324.

43. Lages, C. R., Pfajfar, G., \& Shoham, A. (2015). Challenges in conducting and publishing research on the Middle East and Africa in leading journals. International Marketing Review, 32(1), 52-77.

44. Land, M. (1992). Ivoirian television, willing vector of cultural imperialism. Howard Journal of Communications, 4(1-2), 10-27.

45. Laurent, A. (1986). The cross-cultural puzzle of international human resource management. Human Resource Management, 25(1), 91-102.

46. Leach, M., \& Mearns, R. (1996). Environmental change and policy. In Leach, M., \& Mearns, R. (Eds.). The Lie of the Land: Challenging Received Wisdom on the African Environment, Oxford: James Currey, UK: 1-33.

47. Lekorwe, M. (2011). The Kgotla and traditional leadership in Botswana. In Ray, D. I., Quinlan T., Sharma, K., Clarke, T. (Eds.). Re-inventing African Chieftaincy in the Age of AIDS, Gender, Governance, and Development, University of Calgary Press: Calgary, Canada: 383-402.

48. Mamman, A., Baydoun, N., \& Adeoye, B. (2009). Transferability of management innovation to Africa: A study of two multinational companies' performance management system in Nigeria. Global Business Review, 10(1), 1-31.

49. Mangaliso, M. P. (2015). Building competitive advantage from Ubuntu: management lessons from South Africa. In Puffer, S. M. (Ed.). International Management: Insights from Fiction and Practice, Routledge, New York, USA: 214-224.

50. Mangaliso, M. P. (2001). Building competitive advantage from Ubuntu: Management lessons from South Africa. Academy of Management Executive, 15(3), 23-33.

51. McDonnell, A., Russell, H., Sablok, G., Burgess, J., Stanton, P., Bartram, T., Boyle, B., Manning, K. (2011). A Profile Human Resource Management in Multinational 
Enterprises Operating in Australia. Victoria University, Australia.

52. McKinsey Global Institute. (2010). Lions on the move: The progress and potential of African economies. Available at: http://www. mckinsey.com/insights/africa/lions_on the move (Accessed 26 August, 2015).

53. Mellahi, K., \& Frynas, J. G. (2003). An exploratory study into the applicability of Western HRM practices in developing countries: an Algerian case study. International Journal of Commerce and Management, 13(1), 61-80.

54. Mellahi, K, \& Mol M. J. (2015). Africa is just like every other place, in that it is unlike any other place. Africa Journal of Management, (ahead-of-print), 1-9. DOI: $10.1080 / 23322373.2015 .1026761$

55. Michalopoulos, S., \& Papaioannou, E. (2013). Precolonial ethnic institutions and contemporary African development. Econometrica, 81(1), 113-152.

56. Michalopoulos, S., \& Papaioannou, E. (2014). National institutions and subnational development in Africa. The Quarterly Journal of Economics, 129(1): 151-213.

57. Michalopoulos, S., \& Papaioannou, E. (2015). On the ethnic origins of African development: Chiefs and precolonial political centralization. Academy of Management Perspectives, 29(1), 32-71.

58. Mudambi, R. (2011). Hierarchy, coordination, and innovation in the multinational enterprise. Global Strategy Journal, 1(3-4), 317-323.

59. Nyuur, R. B., Osabutey, E. L., \& Debrah, Y. A. (2014). Doing business in Africa. In Nwankwo S, Ibeh K (Eds.). The Routledge Companion to Business in Africa, Routledge: Abingdon, Oxon, UK: 197-204.

60. Osabutey EL, Nyuur RB, Debrah YA. 2015. Developing strategic international human resource capabilities in Sub-Saharan Africa. In Machado, C. (Ed.). International Human Resources Management, Springer International Publishing: Switzerland: 37-51.

61. Peng, M. W. (2014). New research directions in the institution based view. In Multidisciplinary Insights from New AIB Fellows. 10 Oct: 59-78. http://dx.doi. org/10.1108/S1064-485720140000016002 (Accessed 14 October 2015).

62. Perlmutter HV. 1969. The tortuous evolution of the multinational corporation. Journal of World Business, 4(1), 9-18.

63. Prahalad, C. K., \& Doz, Y. L. (1999). The Multinational Mission: Balancing Local Demands and Global Vision. The Free Press, New York. USA.

64. Pudelko, M., \& Harzing, A. W. K. (2007). Country-of-origin, localization, or dominance effect? An empirical investigation of HRM practices in foreign subsidiaries. Human Resource Management, 46(4), 535-559. 
65. Rosenzweig, P. M., \& Nohria, N. (1994). Influences on human resource management practices in multinational corporations. Journal of International Business Studies, 25(2), $229-251$.

66. Sartorius, K., Merino, A., \& Carmichael, T. (2011). Human resource management and cultural diversity: a case study in Mozambique. The International Journal of Human Resource Management, 22(9), 1963-1985.

67. Sayers, A. (2008). Tips and tricks in performing a systematic review. British Journal General Practice, 58(547), 136-136.

68. Schneider, S. C. (1988). National vs. corporate culture: Implications for human resource management. Human Resource Management, 27(2), 231-246.

69. Smith, P. B. (2008). Indigenous Aspects of Management. In Smith, P. B., Peterson, M. F., \& Thomas, D. C. (Eds.). The handbook of cross-cultural management research, Sage: Thousand Oaks, CA: 319-334.

70. Tayeb, M. H. (2005). International Human Resource Management: A Multinational Company Perspective. Oxford University Press, Oxford: England.

71. The Economist. (2005). Different skills required. 30 June: 1-3. Available at: www. economist.com/node/4138482 (accessed 13 September 2015).

72. Weaver, G. (1999). American cultural values. Kokusai Bunka Kenshu (Intercultural Training), 14-20. Available at: trends.gmfus.org/doc/mmf/American\%20Cultural\%20 Values.pd (Accessed 28 August 2015).

73. Wocke, A., Bendixen, M., \& Rijamampianina, R. (2007). Building flexibility into multi-national human resource strategy: a study of four South African multi-national enterprises. The International Journal of Human Resource Management, 18(5), 829-844.

74. Wright, P. M., \& McMahan, G. C. (1992). Theoretical perspectives for strategic human resource management. Journal of Management, 18(2), 295-320.

75. Wright, P. M. (1998). Introduction: Strategic human resource management research in the $21^{\text {st }}$ century. Human Resource Management Review 8(3), 187-191.

76. Xing, Y., Liu, Y., \& Tarba, S. Y., \& Cooper, C. L. (2014). Intercultural influences on managing African employees of Chinese firms in Africa: Chinese managers' HRM practices. International Business Review, Advance online publication June 25, doi:10.1016/j.ibusrev.2014.05.003.

77. Yahiaoui, D. (2015). Hybridization: striking a balance between adoption and adaptation of human resource management practices in French multinational corporations and their Tunisian subsidiaries. The International Journal of Human Resource Management 26(13), 1665-1693. 